ИЗВЕСТИЯ АКАДЕМИИ НАУК ЭСТОНСКОИ ССР. ТОМ 27 ХИМИЯ, 1978, № 4

\author{
И. КЛЕСМЕНТ, Нейла ЛИЛЛЕП, Эда УРМЕТ
}

удК 631.441 .5

\title{
ГЕОХИМИЯ ПОЧВЕННЫХ ЛИПОИДОВ С ТОЧКИ ЗРЕНИЯ ХИМИКОВ
}

В настоящей работе представлены результаты продолжения исследований состава углеводородов почвы. Приводятся также данные по жирнокислотной части почв. В нашем прежнем сообщении [1] было показано, что почвенные углеводороды с поля вблизи пос. Люганузе (КохтлаЯрвеский р-н) имеют своеобразный состав: для н-парафинов характерно бимодальное распределение, в пробах летних месяцев много низкокипящих углеводородов $\left(<\mathrm{C}_{18}\right)$ и относительно мало длинноцепочечных парафинов с большим и нечетным числом углеродных атомов $\left(\mathrm{C}_{29}, \mathrm{C}_{31}\right.$, $\mathrm{C}_{33}$ ), которые, по литературным данным, являются главными компонентами почвенных углеводородов.

Одновременно (1975) были исследованы почвы из других местностей, в которых был другой, более обычный состав углеводородов. Для накопления большего количества экопериментального материала в 1976 и 1977 гг. проводился отбор проб из трех почвенных сред, сильно различающихся по составу: 1) садовая почва с территории г. Кивиыли, 2) строительный песок (оттуда же), 3) лесная почва из дер. Васкяла Харьюското р-на. В отличие от других проб, песок до отбора первой пробы был пропитан противоэрозионным средством - нэрозином (средняя фракция сланцевой смолы). Это было связано с целью параллельно проводимой работы по исследованию превращения нэрозина на открытом воздухе. Необходимо отметить, что наличие нэрозина в песке на результаты настоящей работы (определение углеводородного и жирнокислотного состава липоидов) нисколько не повлияло.

Отбор проб и их анализ проводились так же, как в [1]. Пробы отбирались в последней декаде каждого месяца (№ пробы в таблице соответствует номеру месяца взятия пробы). Липоиды экстрагировались смесью спирта и бензола и разделялись на группы способом препаративной тонкослойной хроматографии [²]. Из другой части экстракта омылением спиртовой щелочью выделялись кислоты. Выходы и груп. повые составы липоидов представлены в таблице. Индивидуальный состав углеводородов определялся газохроматографически на аппаратє Хром-4, состав карбоновых кислот - на ЛХМ-8МД-5 с использованием. неподвижных фаз различной полярности.

Для общей характеристики липоидов устанавливался их элементный состав и снимались ИК-спектры. Элементный состав почвенных липоидов не зависит от месяца отбора пробы. Липоиды садовой почвы содержали (вес. \%): $\mathrm{C}-74,2-75,8, \mathrm{H}-9,0-9,8$, гетероэлементы - $14-16$. Состав липоидов полевой почвы, исследованных нами ранее [1]: С - 
Групповой состав почвенных липоидов

\begin{tabular}{c|c|c|c|c|c|c}
\hline $\begin{array}{c}\text { Месяц } \\
\text { отбора } \\
\text { пробы }\end{array}$ & $\begin{array}{c}\text { Выход, } \\
\text { вес. \% }\end{array}$ & $\begin{array}{c}\text { Алифати- } \\
\text { ческие } \\
\text { угеводо- } \\
\text { роды }\end{array}$ & $\begin{array}{c}\text { Алкил- } \\
\text { бензолы }\end{array}$ & $\begin{array}{c}\text { Полицик- } \\
\text { лическая } \\
\text { арома- } \\
\text { тика }\end{array}$ & $\begin{array}{c}\text { Нейтраль- гетеро- } \\
\text { атомные со- } \\
\text { единения }\end{array}$ & $\begin{array}{c}\text { Карбоно- } \\
\text { вые кис- } \\
\text { лоты }\end{array}$ \\
\hline
\end{tabular}

$\begin{array}{rlllllll}\text { V } & 0,663 & 8,3 & 2,1 & 4,5 & 45,0 & & 40,1 \\ \text { VI } & 0,665 & 7,3 & 7,4 & 6,5 & 41,3 & & 37,5 \\ \text { VII } & 0,700 & 2,8 & 0,6 & 0,8 & 53,3 & & 24,2 \\ \text { VIII } & 0,662 & 5,0 & 0,9 & 2,9 & & 91,2 & \\ \text { IX } & 0,650 & 9,5 & 3,9 & 6,0 & & 80,6 & \\ \text { X } & 0,604 & 4,4 & 2,2 & 3,7 & 49,8 & & 39,9\end{array}$

Строительный песок, перемешанный с нэрозином

\begin{tabular}{rrrrrrrr} 
V & 0,184 & 9,7 & 4,8 & 4,5 & & 81,0 & \\
VI & 0,120 & 10,7 & 4,4 & 5,0 & & 79,9 & \\
VII & 0,079 & 17,6 & 4,0 & 6,2 & & 72,2 & \\
VIII & 0,105 & 4,1 & 4,0 & 1,6 & 62,9 & & 27,4 \\
IX & 0,080 & 21,2 & 7,3 & 3,9 & & 67,6 & \\
X & 0,068 & 9,5 & 4,9 & 5,5 & 54,7 & & 25,4 \\
XI* & 0,055 & 10,7 & 6,2 & 4,2 & 43,9 & & 35,0 \\
\hline
\end{tabular}

* Песок без нэрозина.

$72,6-73,3$, H $-10,8-11,5$, гетероэлементы - 15-16. Почвенные липоиды более южных районов СССР, выделенные из черноземов и красноземов $\left[{ }^{3}\right]$, содержат углерода и водорода меньше, а гетероэлементов больше, чем исследованные нами.

Некоторые данные о составе почвенных липоидов можно получить также по их ИК-спектрам. Спектры всех исследованных проб похожи. Широкая, но малоинтенсивная полоса поглощения в области $3400-$ $3100 \mathrm{~cm}^{-1}$ отвечает колебаниям водородной связи (ОН-группы). Серия полос в диапазоне $2918-2850,1480,1400-1380$ cм $^{-1}$ отвечает колебаниям СН-группы, а также симметричным и асимметричным колебаниям $\mathrm{CH}_{2}$ - и $\mathrm{CH}_{3}$-прупп. Характерная полоса в области $720 \mathrm{~cm}^{-1}$ соответствует колебаниям цепей $\left(\mathrm{CH}_{2}\right)_{n}$, где $n>4$. Для всех спектров характерны интенсивные полосы $1710-1730 \mathrm{~cm}^{-1}$, лежащие в области поглощения карбоксильных и карбонильных групп. Судя по ИК-спектрам, липоиды характеризуют алифатические структуры 'и- кислородсодержащие функциональные группы.

Содержание липоидов в садовой почве в течение вегетационного периода изменяется мало (см. таблицу). Их концентрация $(0,6-0,7 \%)$ в несколько раз больше, чем в полевой почве $(0,08-0,12 \%)$ [']. Но концентрация алифатических углеводородов в экстракте (4-10\%) в несколько раз ниже, чем в полевых условиях $(25-35 \%)$. Учитывая выходы липоидов и содержание углеводородов в них, оказывается, что концентрация парафинов в садовой и полевой почве одинакова. Содержание липоидов садовой почвы повышено за счет полярных соединений, значительную долю которых составляют кислоты. Количество липоидов в песке, в котором гумус и фотосинтезирующая растительность отсутствуют, в десять раз меньше, чем в садовой ппочве; оно составляет после вычета нэрозина 0,05-0,07\%.

Состав почвенных парафинов по месяцам представлен на рис. 1. Он существенно отличается от состава, который был установлен для парафинов полевой почвы [']. Парафины садовой почвы имеют исключи- 

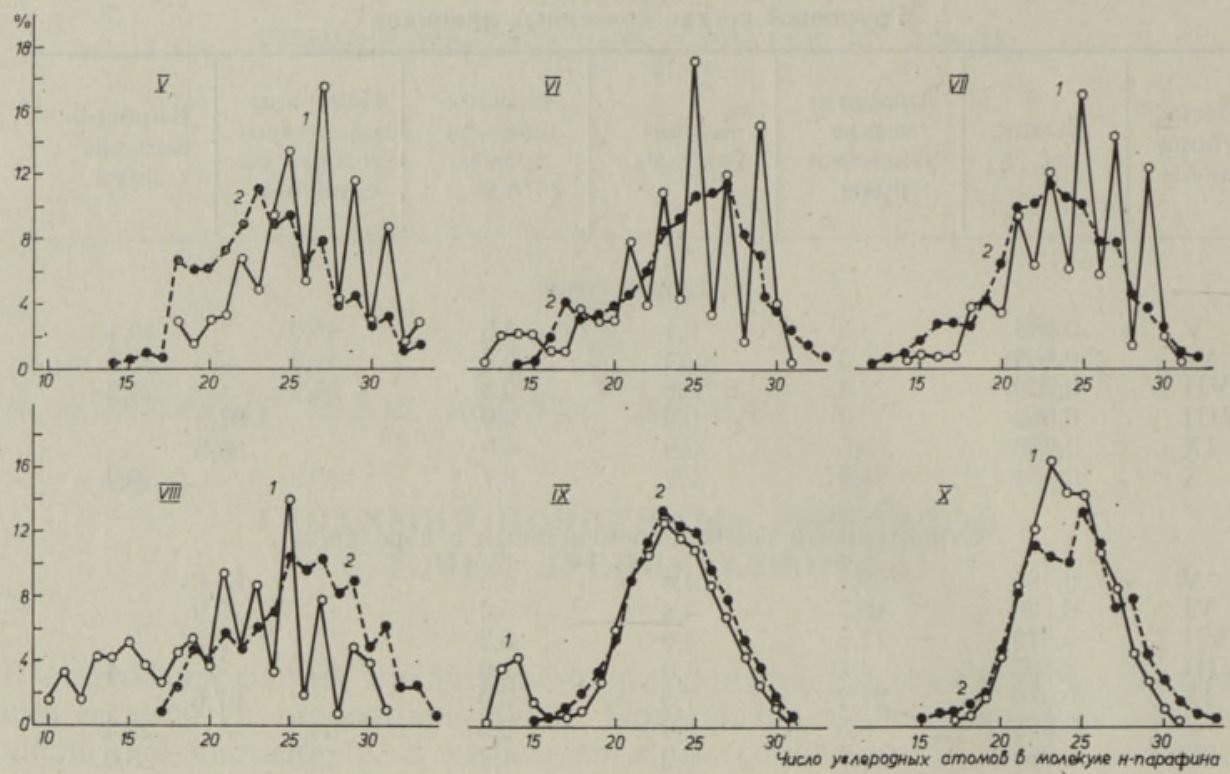

Рис. 1. Сезонное изменение состава почвенных $\mu$-парафинов. $\mathrm{V}-\mathrm{X}$ соответствуют очередным номерам месяцев отбора проб (см. таблицу); 1 - парафины садовой почвы, 2 - парафины песка.

тельно нормальное строение, изопреновые углеводороды присутствуют в следовых количествах, гомологов с низким молекулярным весом $\left(<\mathrm{C}_{20}\right)$ мало, главные компоненты - $\mathrm{C}_{23}, \mathrm{C}_{25}, \mathrm{C}_{27}$ и $\mathrm{C}_{29}$, состав парафинов летом изменяется незначительно, но с конца сентября - коренным образом. Все эти показатели не были характерны для полевых углеводородов.

Углеводороды песка, в отличие от других липоидов, имеют невысокую «нечетность», которая осенью полностью исчезает. Самое интересное явление - то, что осенью углеводороды в песке и садовой почве имеют точно совпадающий состав и одинаково низкий коэффициент «нечетности» (КН - соотношение концентраций парафинов с нечетным и четным числом атомов углерода).

Происхождение почвенных парафинов уже обсуждалось при исследовании полевых углеводородов [']. Углеводороды с высоким КН образуются в высших фотосинтезирующих растениях, и после распада последних самые стабильные их составляющие (вооки) сохраняются в почве. Углеводороды с КН, близким к единице, имеют бактериальное происхождение, в нашем случае углеродные цепи бактериальных парафинов, образующихся осенью, немного короче, чем у восковых парафинов. Основная часть содержит $21-27$ атомов углерода, высшую концентрацию имеет $\mathrm{C}_{23}$. Бактериальные парафины образуются также летом, на это указывает то обстоятельство, что с укорочением углеродной цепи парафинов их КН уменьшается: в период июнь-август $\mathrm{C}_{21}$ и $\mathrm{C}_{23}$ имеют средний $\mathrm{KH}-1,9$, а парафины $\mathrm{C}_{25}, \mathrm{C}_{27}$ и $\mathrm{C}_{29}-4,5$. Подобное явление было отмечено также у полевых парафинов ['].

Часть парафинов, присутствующих в песке, может иметь экзогенное происхождение, так как парафины подобного состава присутствуют в выхлопных газах двигателей внутреннего сгорания и в воздухе [4,5], где источники их образования самые различные. Парафины с КН, близким к единице, с максимумом при $\mathrm{C}_{23}$ установлены в эстонском горючем 
Рис. 2. Хроматограмма парафинов лесной почвы мая месяца. Номера пиков показывают количество углеродных атомов в соответствующих н-парафинах; $i 16$ - $i 19$ - изопреновые углеводороды. (Хроматограф Хром-4, колонка 50 м $\times 0,2$ мм, неподвижная фаза - дексил 300 , $2{ }^{\circ} \mathrm{C} /$ мин $)$.

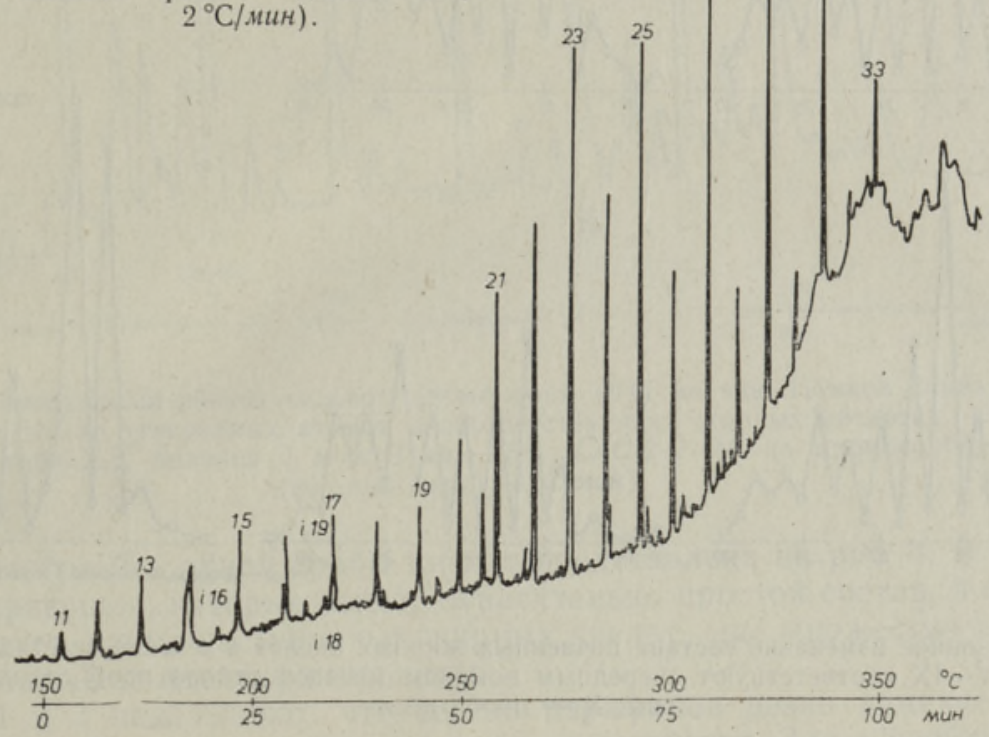

сланце-кукерсите [6] и в ряде других горючих сланцев $[7,8]$, в каменном угле [ $\left.{ }^{9}\right]$, в гуминовых и фульвокислотах, выделенных из черноземной почвы $\left[{ }^{10}\right]$. Нами было ранее установлено, что такие бактериальные парафины присутствуют также в фульвокислотах, выделенных из каменного угля месторождения Шураб Таджикской ССР.

С апреля по октябрь были выделены липоиды из лесной почвы. Их выход составлял $0,11-0,18 \%$, содержание в них парафинов - 5-10\%. Судя по этим данным, концентрация парафинов в лесной почве в несколько раз ниже, чем в садовой и полевой почве. Парафины представлены преимущественно гомологами, имеющими длинную углеродную цепь, - типичными восковыми парафинами (рис. 2). В основном количестве парафинов изменения в течение летнего периода были незначительные, 'и резкого перехода к бактериальному режиму не наблюдалось. В весенних пробах лесной почвы было установлено небольшое количество $\boldsymbol{H}$-1-олефинов (рис. 2), повышенную концентрацию имели $\mathrm{C}_{14}$ и $\mathrm{C}_{16}$ - гомологи с четным числом углеродных атомов. Наличие следовых количеств олефинов было обнаружено также в некоторых пробах после их длительното выдерживания (несколько месяцев) в лаборатории. В живых организмах углеводородов мало, особенно олефинов. Предполагается, что олефины образуются в результате дегидратации жирных спиртов, которые содержат четное число углеродных атомов. Такой механизм образования олефинов возможен в данном случае. Однако восковые спирты имеют более длинную углеродную цепь, чем это было установлено для олефинов. По мнению многих исследователей, процесс биологичеокого окисления парафинов идет через дегидрирование с промежуточным образованием олефинов, которые затем окисляются до спиртов, альдегидов, кетонов и жирных кислот. Но легче окисляются 

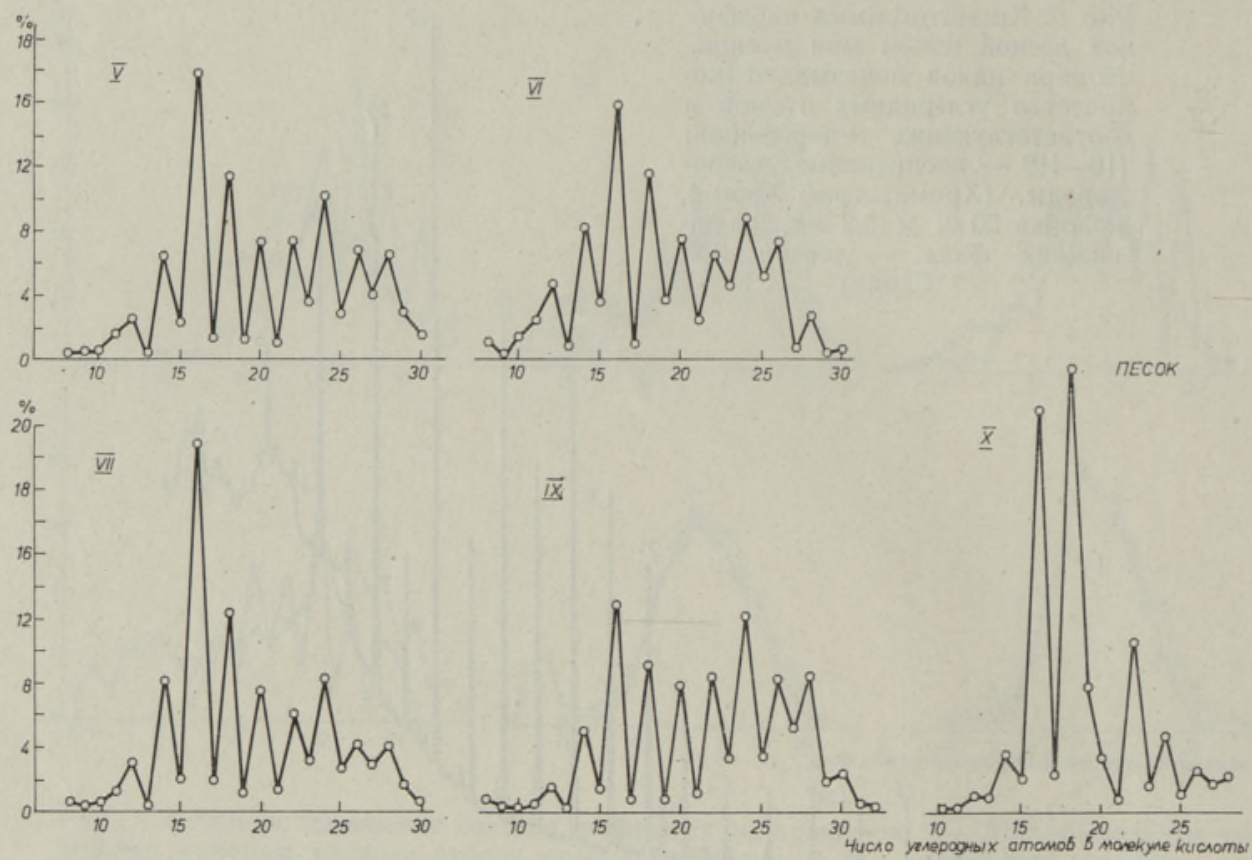

Рис. 3. Сезонное изменение состава почвенных жирных кислот в течение вегетационного периода. V-IX соответствуют очередным номерам месяцев отбора проб садовой почвы; X - проба песка.

соединения с длинной углеродной цепью, и бактериальные процессы проходят неселективно - эти показатели не согласуются с данными настоящей работы.

Вторая важная группа соединений в почвенных липоидах - жирные кислоты. Их количество превышает количество углеводородов. Состав кислот по месяцам изображен на рис. 3. Кислоты, как продукты биосинтеза, представлены преимущественно «четными» гомологами. В данном случае самый интересный вопрос - генетическая связь между $\boldsymbol{H}$-парафинами и жирными кислотами. Предполагается, что в организмах и в седиментах парафины образуются небиологическим путем при декарбоксилировании жирных кислот. Поэтому целесообразно сравнить состав парафинов и кислот. В отличие от парафинов, кислоты представлены гомологами с более короткой цепью $\left(\mathrm{C}_{8}-\mathrm{C}_{32}\right)$, во всех пробах основным компонентом является пальмитиновая кислота $\left(\mathrm{C}_{16}\right)$, которая обычно превалирует также и в других биологических продуктах. В течение вегетационного периода состав кислот изменяется мало, изменений не наблюдается и осенью. Коэффициент четности (КЧ) - отношение кислот с четным числом углеродных атомов к кислотам с нечетным числом углеводородных атомов, в отличие от парафинов, в начале гомологического ряда выше, чем в конце. Для $\mathrm{C}_{14}-\mathrm{C}_{20}$ КЧ составляет 7,6 , а в длинноцепочечной области $\mathrm{C}_{22}-\mathrm{C}_{28}$ он равен 2,7 . Учитывая, что при декарбоксилировании этот коэффициент (показатель биологического происхождения) не может увеличиваться (в длинноцепочечной области кислоты имеют КЧ $=2,7$, а парафины, соответственно, - $\mathrm{KH}=4,5)$, суммарный продукт найденных в почве кислот не может быть источником почвенных парафинов с высоким КН. Парафины бактериальното происхождения, конечно, могут образоваться из длинноцепочечных кислот. 
личества органических остатков, служащих питательной средой для бактерий. Мы не можем сказать, из каких микроорганизмов образуются наши «бактериальные парафины». Предположительно это - аэробные целлюлозоразлагающие бактерии или почвенные грибы, водоросли, простейшие и т. д.

В ходе настоящей работы появилось много материала; который расходится с представленными в литературе данными и требует дальнейшего исследования. По литературным данным, бактериальные парафины имеют более короткую $\left(<\mathrm{C}_{20}\right)\left[{ }^{14}\right]$ или более длинную углеродную цепи $\left(\mathrm{C}_{25}-\mathrm{C}_{31}\right)\left[{ }^{15}\right]$, чем наши парафины. Распространено мнение, что бактериальные парафины и кислоты, в том числе, присутствующие в геосфере, имеют разветвленную углеродную цепь [ $\left.{ }^{16}\right]$. В наших пробах изоструктуры присутствовали в следовых количествах. Считается, что главные компоненты почвенных липоидов - длинноцепочечные кислоты $\mathrm{C}_{22}-$ $\mathrm{C}_{34}\left[{ }^{17}\right]$, которые в наших пробах имели подчиненное значение. Можно только предположить, как образуются почвенные липоиды и как происходит их дальнейшая трансформация.

В зависимости от места взятия пробы составы липоидов существенно различались. Углеводороды и кислоты песка могли образовываться там же, но могли быть и постороннего (экзогенного) происхождения. В составе почвенных липоидов отражаются многие химические, биологические, почвенные, метеорологические и т. д. факторы, для выяснения взаимосвязи между которыми требуется дальнейшая работа.

Авторы выражают благодарность С. Салусте и Е. Бондарь за проведение газохроматографического анализа.

\section{ЛИ Т Е Р А Т У Р А}

1. Клесмент И., Лиллеп Н. К геохимии почвенных углеводородов Северной Эстонии. - Изв. АН ЭССР, Хим., 1978, т. 27 , № 1, с. $8-14$.

2. K1 èsment, I. Application of chromatographic methods for biogeochemical investigations. - J. Chromatogr., 1974, v. 95, p. 705-714.

3. Ам мосов а Я. М., Орлов Д. С., Садовникова Л. К. Почвенные липоиды. - В кн.: Природа органического вещества современных и ископаемых осадков. M., 1973, c. $91-101$.

4. H a user, T. R., Pattison, J. N. Analysis of aliphatic fraction of air particulate matter. - Environ. Sci. Technol., 1972, v. 6, N 6, p. 549-555.

5. Gelpi, E., Nooner, D. W., Oró, J. Ubiquiti of hydrocarbons in nature: aliphatic hydrocarbons in dust samples. - Geochim. et cosmochim. acta, 1970, v. 34 , p. $421-425$.

6. У ро в К., Р янду Р А., Кл есм ен т И., Э й зен О. Алифатические углеводороды в кукерсите и близлежащей среде. - Изв. АН ЭССР, Хим. Геол., 1976, т. 25, № 3, с. $179-186$.

7. Гуляев а Н. Д., А рефьев О. А., Петров А. А. Закономерности распределения нормальных и изопреноидных алканов в горючих сланцах. - Химия тв. топлива, 1977 , № 6, с. $25-31$.

8. У ров К. Э., Листрем А. И. Сравнительная характеристика органического вещества девонского и юрского горючих сланцев Ухтинского месторождения. Химия тв. топлива, 1977 , № 2, с. $71-77$,

9. A 11 a n, J., Douglas, A. G. Variations in the content and distribution of $n$-alkanes in a series of carboniferous vitrinites and sporinites of bituminous rank. - Geochim. et cosmochim. acta, 1977, v. 41, N 9, p. 1223-1230.

10. Schnitzer, M., Neyroud, J. A. Alkanes and fatty acids in humic substances. - Fuel, 1975 , v. 54 , N 1, p. 17-19.

11. Matsuda, H., Koy ama, T. Early diagenesis of fatty acids in lacustrine sediments - I. - Geochim. et cosmochim. acta, 1977, v. 41, p. 777-783.

12. Johnson, R. W., Galder, J. A. Early diagenesis of fatty acids and hydrocarbons in a salt marsh environment. - Geochim. et cosmochim. acta, 1973, v. 37 , p. $1943-1955$.

13. Р ахно П. Х. Сезонная количественная динамика почвенных бактерий. Таллин, изд. АН ЭССР, 1964. 
14. Дед юхина Э. Г., Анд ре ев Л. В., Попков Г. П., Е рошин В. К. Биосинтез углеводородов алканокисляющими микроорганизмами. - Микробиология, 1972 , № 4, c. $664-667$.

15. Jones, J. G. Studies on lipids of soil micro-organisms with particular reference to hydrocarbons. - J. Gen. Microbiol., 1969, v. 59, p. 145-152.

16. Ф и з е р Л., Ф и зе р М. Органическая химия. Т. 2. М., 1970, с. 618.

17. Morrison, R. I. Soil lipids. - In: Organic geochemistry, ed. by G. Eglinton and M. T. J. Murphy. Berlin, 1969, p. 558-575.

\author{
Ннститут химии \\ Академии наук Эстонской ССР
}

Поступила в редакцию
6/II 1978

\title{
I. KLESMENT, Neila LILLEP, Eda URMET
}

\section{MULLALIPIIDIDE GEOKEEMIAST}

Mullalipiidide kohta leidub kirjanduses mitmesuguseid andmeid. Käesolevas töös uuritud aiamulla pōhilised n-parafiinid on $\mathrm{C}_{20}-\mathrm{C}_{29}$ (kõige rohkem on $\mathrm{C}_{23}$ ); metsamullas on rohkem pikema ahelaga parafiine. Vegetatsiooniperioodil sisaldab enamik parafiine paaritut arvu süsinikuaatomeid, sügisel nende koostis ühtlustub, sest parafiine toodavad ainult bakterid. Liivas leidub ainult bakteriaalseid parafiine.

Mulla rasvhapped on lühema ahelaga kui parafiinid $\left(\mathrm{C}_{10}-\mathrm{C}_{30}\right)$; põhilised homoloogid kōigis proovides on $\mathrm{C}_{16}$ ja $\mathrm{C}_{18}$. Enamik parafiine ei moodustu rasvhapetest. Mullalipiidide koostist mõjustavad paljud tegurid.

\section{KLESMENT, Neila LILLEP, Eda URMET}

\section{ON THE GEOCHEMISTRY OF SOIL LIPIDS}

\section{(An approach of chemists)}

In the garden soil $n$-paraffins are mostly represented by $C_{20}-C_{29}, C_{23}$ prevailing, but in the forest soil paraffins have mostly a longer chain. During the vegetation period the majority of paraffins are odd carbon numbered, while in autumn their composition is levelled since paraffins are produced only by bacteria. In sand only bacterial paraffins are present.

Soil fatty acids have shorter chains than paraffins $\left(\mathrm{C}_{10}-\mathrm{C}_{30}\right)$. The main homologues in all samples are $C_{16}$ and $C_{18}$. The majority of paraffins are not formed from fatty acids. The composition of soil lipids depends on many factors. 